\title{
Ectocervical Biopsy
}

National Cancer Institute

\section{Source}

National Cancer Institute. Ectocervical Biopsy. NCI Thesaurus. Code C51630.

Removal of tissue from the ectocervix for microscopic examination. 